\title{
The Effects of Detraining on Cardiovascular Parameters in Distance Runners
}

ISSN: 2637-7934

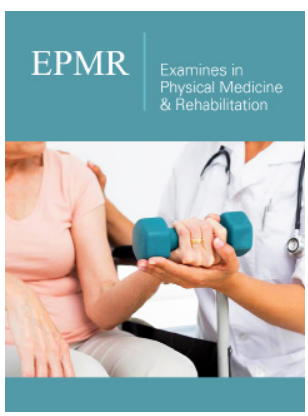

*Corresponding author: Gerasimos V Grivas, School of Physical Education and Sports Science, Greece

Submission: 棒October 14, 2019

Published: 甄October 31, 2019

Volume 2 - Issue 5

How to cite this article: Gerasimos $\mathrm{V}$ Grivas. The Effects of Detraining on Cardiovascular Parameters in Distance Runners. Examines Phy Med Rehab.2(5). EPMR.000546.2019.

DOI: 10.31031/EPMR.2019.02.000546.

Copyright@ Gerasimos V Grivas, This article is distributed under the terms of the Creative Commons Attribution 4.0 International License, which permits unrestricted use and redistribution provided that the original author and source are credited.

\author{
Gerasimos V Grivas* \\ School of Physical Education and Sports Science, Greece
}

\begin{abstract}
Detraining is the reduction of performance that happens after the cessation of training and is reflected by anatomic and physiologic changes. The purpose of this study was to investigate the effects of reduce training on cardiovascular parameters in distance runners. Many studies showed reduce of $\mathrm{VO}_{2}$ max and anaerobic threshold after detraining. On the other hand, only one study examined the effect of detraining on running economy and did not observe a decline.
\end{abstract}

Keywords: Detraining; $\mathrm{VO}_{2}$ max; Anaerobic threshold; Running economy; Distance runners

\section{Introduction}

Detraining is the partial or complete loss of training-induced adaptations, in response to an insufficient training stimulus [1]. In general, significant conditioning is lost after 2-6 weeks of insufficient training. In other words, the individual becomes 'less fit' [2]. Therefore, recognizes that stopped, or reduction of a training stimulus leads to a decline in specific conditioning. The rate of 'fitness' decrement with training cessation does vary from one physiological parameter to the another and so are here divided logically. The most important parameters that are affected from reduce training or detraining is maximal oxygen uptake $\left(\mathrm{VO}_{2} \mathrm{max}\right)$, anaerobic or lactate threshold and running economy. Therefore, the purpose of this study was to investigate the effects of reduce training on cardiovascular parameters in distance runners.

\section{Maximal Oxygen Uptake (VO2 max)}

When runners don't train for a couple of weeks, the resulting drop in $\mathrm{VO}_{2}$ max is caused primarily by a loss in plasma volume, which is a key aspect of detraining. More specifically, the study of Houston et al. [3] showed that 15 days of inactivity led to $4 \%$ reductions in $\mathrm{VO}_{2}$ max in well-trained endurance runners. Moreover, Houmard et al. [4] \& Houmard JA et al. [5] reported that $\mathrm{VO}_{2}$ max also decreased by $4.7 \%$ in a group of endurance-trained runners after $14 \mathrm{~d}$ of training cessation. Also, Coyle et al. [6] showed that 2-4 weeks of stopped training in eight endurance trained subjects reported $6 \% \mathrm{VO}_{2}$ max declined during upright exercise. Furthermore, Mankowitz et al. [7] studied a group of trained runners who stopped training for 14-22 days and reported $12 \% \mathrm{VO}_{2}$ max declines. In a similar study, Martin et al. [8] showed that after of 3-8 weeks physical deconditioning in highly trained runners $\mathrm{VO}_{2}$ max reduction by $20 \%$. Coyle et al. [9] observed that seven endurance-trained subjects stopped training for 84 days, and their $\mathrm{VO}_{2}$ max declined by 7 and $16 \%$ in 21 and 56 days, respectively, it then stabilized at that level, which was still $17.3 \%$ higher than that of sedentary control subjects. In conclusion, many studies indicate that $\mathrm{VO}_{2}$ max of highly trained athletes decreases progressively and proportionally to the initial $\mathrm{VO}_{2}$ max during the first 8 week of training cessation $[10,11]$.

\section{Anaerobic or Lactate Threshold}

Only a few studies examined the effect of detraining on anaerobic and lactate threshold. In the study of Ready et al. [12] reported that 9 weeks of training is of sufficient duration to cause a significant alteration in anaerobic threshold. Loss of this training gain occurs rapidly and appears to be similar to changes in $\mathrm{VO}_{2}$ max. Coyle et al. [13] examined the effects of detraining after 12, 21, 56 and 84 days. After detraining of 21, 56 and 84 days showed reduce of anaerobic threshold by $11.5 \%, 20.3 \%$ and $23.5 \%$ respectively. Pavlik et al. [14] reported 
on 40 observations on highly trained road cyclists and endurance runners who, for various reasons, stopped training for 60 days. They observed a linear decline in the athletes' lactate threshold throughout the initial 45 days of training stoppage, with no further change thereafter.

\section{Running Economy}

Only one study examined the effect of detraining in running economy. Houmard et al. [4] did not observe a decline in running economy at submaximal exercise intensities (75 and $90 \%$ of $\mathrm{VO}_{2}$ max) in their 12 distance runners after 14 days of detraining, which suggests that the short-term training cessation-induced performance impairment was primarily because of the loss in cardiorespiratory fitness suffered by the athletes.

\section{Conclusion}

When physical training is markedly reduced or stopped for a period longer than 4 weeks, the $\mathrm{VO}_{2}$ max of highly trained athletes declines by 6 to $20 \%$, but usually remains above sedentary values. Therefore after 21-84 days of detraining observed reduce of anaerobic threshold by $11.5-23 \%$. Finally, after 14 days of detraining did not showed a reduce in running economy.

\section{References}

1. Mujika I, Padilla S (2000) Detraining: Loss of training-induced physiological and performance adaptations. Part I: Short term insufficient training stimulus. Sports Med 30(2): 79-87.

2. Godfrey RJ, Ingham SA, Pedlar CR, Whyte GP (2005) The detraining and retraining of an elite rower: A case study. J Sci Med Sport 8(3): 314-320.

3. Houston ME, Bentzen H, Larsen H (1979) Interrelationships between skeletal muscle adaptations and performance as studied by detraining and retraining. Acta Physiol Scand 105(2): 163-170.
4. Houmard JA, Hortobágyi T, Johns RA, Bruno NJ, Nute CC, et al. (1992) Effect of short-term training cessation on performance measures in distance runners. Int J Sports Med 13(8): 572-576.

5. Houmard JA, Hortobágyi T, Neufer PD, Johns RA, Fraser DD, et al. (1985) Training cessation does not alter GLUT-4 protein levels in human skeletal muscle. J Appl Physiol 74(2): 776-781.

6. Coyle EF, Hemmert MK, Coggan AR (1985) Effects of detraining on cardiovascular responses to exercise: Role of blood volume. J Appl Physiol 60(1): 95-99.

7. Mankowitz K, Seip R, Semenkovich CF, Daugherty A, Schonfeld G (1992) Short-term interruption of training affects both fasting and postprandial lipoproteins. Atherosclerosis 95(2-3): 181-189.

8. Martin WH, Coyle EF, Bloomfield SA, Ehsani AA (1986) Effects of physical deconditioning after intense endurance training on left ventricular dimensions and stroke volume. J Am Coll Cardiol 7(5): 982-989.

9. Coyle EF, Martin WH, Sinacore DR, Joyner MJ, Hagberg JM, et al. (1984) Time course of loss of adaptations after stopping prolonged intense endurance training. J Appl Physiol Respir Environ Exerc Physiol 57(6): 1857-1864.

10. Allen GD (1989) Physiological and metabolic changes with six weeks detraining. Aust J Sci Med Sport 21: 4-9.

11. Drinkwater BL, Horvath SM (1972) Detraining effects on young women. Med Sci Sports 4(2): 91-95.

12. Ready AE, Quinney HA (1982) Alterations in anaerobic threshold as the result of endurance training and detraining. Med Sci Sports Exerc 14(4): 292-296.

13. Coyle EF, Martin WH, Bloomfield SA, Lowry OH, Holloszy JO (1985) Effects of detraining on responses to submaximal exercise. J Appl Physiol (1985) 59(3): 853-859.

14. Pavlik G, Bachl N, Wollein W (1986) Effect of training and detraining on the resting echocardiographic parameters in runners and cyclists. International Journal of Sports Cardiology 3(1): 35-45. 